\title{
AN UNDOCUMENTED REVIEW OF THE 1860 LEAVES OF GRASS IN THE LIBERATOR
}

\author{
EZRA GREENSPAN
}

The APPEARANCE OF A REVIEW of the Thayer and Eldridge edition of Leaves of Grass in William Lloyd Garrison's antislavery weekly, the Liberator, may seem an unlikely eventuality. Like most daily, weekly, and monthly periodicals of its day, the Liberator occasionally published original or reprinted poetry, but it was typically the moralistic work of antislavery poets such as John Greenleaf Whittier. Furthermore, the Liberator gave only scant coverage even to new books on current affairs and hardly ever reviewed works in the arts, including volumes of poetry. So why did this rather narrowly focused periodical, whose overriding purpose was to mobilize the public to end slavery in the United States, give space in its pages to a full-scale review of a volume of belletristic poetry-not to mention, in the heat of one of the most rancorous, portentous presidential campaigns in American history?

The most likely explanation lies in the intersecting Boston networks of Leaves of Grass's publishers William Wilde Thayer and Charles Eldridge, and the Liberator's editor-publisher William Lloyd Garrison. The men were well-known to one another as co-workers operating within the tight circles of Boston antislavery politics. During the twelve months (December 1859-December 1860) they operated their publishing house, Thayer and Eldridge were the leading antislavery book publishers in the country, a position augmented when John P. Jewett-their neighbor in the book publishing center of Boston on Washington Street and onetime publisher of antislavery works by Harriet Beecher Stowe, William Wells Brown, and Josiah Henson - suspended his book publishing operations in the summer of 1860. Garrison, for his part, had devoted his life to the antislavery movement and, as owner of the Liberator, operated the most influential periodical in the movement.

From the moment of its inception, the Thayer and Eldridge publishing list was centered on antislavery and radical Republican politics. Its bestselling title was one of its first, a hagiographic biography, The Public Life of Captain Fohn Brown, written at the publishers' suggestion by radical journalist James Redpath and authorized by the Brown family. The 
firm soon followed up that success with additional titles on Brown and other members of his Harpers Ferry militia. Within weeks of the May 1860 Republican national convention, Thayer and Eldridge rushed into print campaign biographies of William Seward and Abraham Lincoln by radical journalist Richard Hinton; likewise in June they were quick to run off an extensive printing of Charles Sumner's widely publicized recent Congressional diatribe The Barbarism of Slavery. In fall they published William Douglass O'Connor's antislavery novel Harrington and contracted, through Lydia Maria Childs, to publish Harriet Jacobs's Incidents in the Life of a Slave Girl. Thayer and Eldridge advertisements running in October and November for their forthcoming works in newspapers in New York and Boston (including in the Liberator) routinely included O'Connor's Harrington, Jacobs's Incidents, and Whitman's newest volume of poetry Banner at Day-Break. ${ }^{1}$

Furthermore, both Thayer and Eldridge were themselves actively involved in antislavery politics. They were most directly concerned with dissemination and protection of the legacy of John Brown. The two men channeled a portion of the revenue from The Public Life of Captain Fohn Brown to Brown's family, and they maintained close ties to members of the band who survived. ${ }^{2}$ When one of Brown's suspected accomplices, Frank Sanborn, was brought to trial in Boston in April, the two men were present in the courtroom, armed and prepared to intervene if necessary, although action proved unwarranted when the presiding judge released Sanborn to his own recognizance. ${ }^{3}$ Later that year, with the first anniversary of Brown's execution looming, Thayer and Redpath were among the organizers of the December 3, 1860, public commemoration at Boston's Tremont Temple, at which a number of speakers addressed a raucous audience. One of the most hostilely received was Frederick Douglass, who was forcibly assaulted as he approached the speaker's podium and then heckled as he attempted to deliver his remarks.

Thayer and Eldridge esteemed Garrison as the leader of the abolition movement in Boston, but the primary basis of their dealings with him during 1860 was strictly professional. Throughout the year they advertised their works in the Liberator, a decision dictated by the overlapping readerships of their books and Garrison's newspaper. Few other publishers or proprietors more consistently advertised in the paper that year. Among the various titles Thayer and Elder advertised was Leaves of Grass, even though it bore no obvious connection to the general run of antislavery works that more typically filled their advertisements in the paper.

If advertisements for Leaves in the Liberator were incongruous, no less so was a review of Leaves in its pages. Why the book was reviewed in its pages, and on whose initiative, is as puzzling a question as is why it was advertised there in the first place. As a generality, puffs, notices, and 
even full-length reviews were commonly printed in antebellum America by arrangement between publishers, one favor often as not returned for another. The publication of this review of Leaves may well have been one such case. Somewhat less commonly, a forward author might also take the lead, and few authors of this period were more forward in terms of self-promotion than Whitman. But Whitman's direct involvement in the affair seems unlikely. He had little professional or personal connection to the Liberator, a periodical too radical for his political views and too narrow and strident for his taste, and the review itself is written in a language too politely learned to raise even the slightest possibility that it was his own. If there is any plausible explanation linking Whitman directly or indirectly to the review, it would be that he had local friends or acquaintances who could have acted as go-betweens with Garrison, whether with or without Whitman's direct knowledge. The two most likely candidates would have been the radical journalists James Redpath and Richard Hinton, activists in the antislavery movement, house authors with Thayer and Eldridge, and warm friends of both Whitman and Garrison. It was Hinton who had encouraged Thayer and Eldridge in the first place to pursue a new edition of Leaves, and both Redpath and Hinton were enthusiastic proponents ready and willing to advocate on the book's behalf. No evidence survives, however, indicating their mediation with Garrison.

A publisher-initiated act seems far more plausible. Most likely Thayer and Eldridge approached Garrison directly. In first offering their services to Whitman as publishers back in January, they had promised to promote Leaves aggressively. To all appearances, they had been true to their word through spring and summer, as the first printing sold out and a second went on sale. Like all publishers during this period, Thayer and Eldridge faced severe distribution problems endemic to a profession trying to deliver its products to a sprawling transcontinental population. With some books, such as O'Connor's Harrington, they resorted to attempts to send an "army" of book agents out into the field; quite plausibly they employed a scaled-back version of this tactic with Leaves. At the same time, they concentrated their money and their attention on the main book buying centers of the Northeast. In New York City, in fact, they deployed a more nearly metropolitan strategy, forming a Whitmaninitiated connection with the poet's primary local booster, Henry Clapp, editor-publisher of the New York Saturday Press. That weekly newspaper had kept Whitman and Leaves steadily (and, for the most part, favorably) before the public eye through spring and summer. Thayer and Eldridge even explored the possibility of buying a share of its ownership from the cash-strapped Clapp before realizing that their own finances were insufficient. Thayer and Eldridge had no such surrogate voice in Boston, but they did have a political ally in Garrison. 
The review of Leaves appeared on September 7 during the weeks leading up to the historic election of November 1860, but the circumstances surrounding its publication are murky. For one thing, its author, who signed himself (it is, to judge from its views and posture, presumably a man) T. V., has not yet been identified. No one with matching initials turns up in the correspondence of either Garrison or Whitman, or in the circles of the Liberator or of Thayer and Eldridge. For another, the review wholly ignores the Liberator's raison d'être, making no mention of racism, slavery, or sectionalism. Although strongly opinionated in its views, it bases it criteria of judgment more nearly on aesthetic than political considerations.

The most conspicuous characteristic of the review is its unqualified praise of Whitman and Leaves as advocates of sexual (rather than political) liberation. The reviewer was as forthright and unequivocal on this issue as was any other contemporaneous reviewer of Leaves in insisting that the charge made against Leaves (and, in particular, the cluster "Enfans d'Adam") of "Phallus worship" more accurately fit the critic than the poet. The reviewer could hardly have been more scorching in deriding the prurience of a society that criticized Whitman as immoderate while restraining itself to naming in public only the "limbs" of tables and chairs. The nearest counterpart to this person's viewpoint was Fanny Fern in her 1856 review of Leaves, but the two critics praised the candor of Leaves from opposite sides of the gender divide. Whereas Fern asserted, "Walt Whitman, the effeminate world needed thee," T.V. lauded him as a "strong, brave lover of man, and uncompromising champion of man's rights."What each saw in the poetry (and especially in "Song of Myself," their primary Leaves proof text) was a "true child of nature" rather than a despoiler of public morality.

While the identity of the reviewer remains indeterminate for the moment, one thing is absolutely clear: we can add a significant text to the list of reviews of Leaves of Grass.

\title{
Southern Methodist University
}

Text of "Walt Whitman," Liberator 30 (September 7, 1860), 143

\author{
WALT WhitMan. \\ Leaves of Grass. Boston: Thayer and Eldridge. \\ Year 85 of The States, (1860-61.)
}

Ekas, ekas, este bibelot, was the exorcism uttered by the grand mystagogue before beginning the ceremony of initiating an aspirant into the mysteries of Bacchus. Now, although we are no mystagogue, and do not profess a knowledge of Bacchic or other mysteries of that sort, we nevertheless feel inclined respectfully to request all merely pedantic, lowminded and profane persons to remove themselves out of this presence, while we speak of a man who is neither low-minded, pedantic, nor profane-Walt Whitman. 
Ruskin says we should "go to nature in all singleness of heart, and walk with her laboriously and trustingly, having no other thought but how best to penetrate her meaning: rejecting nothing, selecting nothing, scorning nothing." That this man has been content thus to look upon nature in her unity and diversity, and to permit her to speak in her own mystic and beautiful language, is the secret of the wonderful fascination of his poems. Many individuals of the "owl species" see nothing but Walt Whitman in these poems. $\mathrm{He}$ - "one of the roughs, disorderly, fleshly and sensual"-intrudes himself upon them in every sentence, and repeats "the unquenchable creed-egotism" on every page. It is undoubtedly a grave offence for an author to thrust his personality between the reader and the truth which the book is intended to embody or set forth. But this is a grand poem of human nature. Man, his origin, nature, and destiny, and the grandeur of these, is the subject; and the author chooses to treat it in the first person, that is all.

"I celebrate myself,

And what I assume you shall assume,

For every atom belonging to me as good belongs to you."

This was the first sentence in the poems as originally published, and to us it was the key to everything that followed. We have been drawn irresistibly to the book, again and again, for there is a simple-minded and strong man speaking in his strength and simplicity. Walt comes to us, with his Leaves of Grass, a true child of nature - of the earth and the stars, and of what is beyond. He scornfully refuses to be judged by an ordinary, conventional standard of Art, for he, indeed, is no artist, but the born priest and hierophant of the mystic, unfathomable universe. He sees that everything is divine; that God is in all, over all, and under all; that there is nothing mean, without a purpose, or out of its place. $\mathrm{He}$ is so full of profound reverence for the old Divine Mother that she, in return, presses him to her bosom, and showers upon him all the wealth of her limitless love- so full of child-like playfulness, confidence and simplicity, that, as he "leans and loafes at his ease, observing a spear of summer grass," all her children press round him with uproarious, sunny laughters, weaving wild flowers in his hair, and kissing him with kisses that breathe the odor of heaven. To him the universe is a miraculum ingens, pregnant with profound mysteries; but he himself is also a miracle - the greatest of miracles. A soft whisper tells him that he is "the acme of things accomplished." All the ages have borne him in solemn procession from chaos and primeval night until now.

Rise after rise bow the phantoms behind me, Afar down I see the huge first Nothing-I know I was even there.

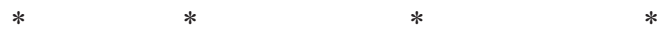

Immense have been the preparations for me, Faithful and friendly the arms that have helped me.

Cycles ferried my cradle, rowing and rowing like cheerful boatmen, For room to me stars kept aside in their own rings, They sent influences to look after what was to hold me.

* * * * *

All forces have been steadily employed to complete and delight me: Now I stand on this spot with my Soul. 
The SOUL!

Forever and forever-longer than soil is brown and solidlonger than water ebbs and flows.

He takes the loftiest views of man, reverences all his parts, and will not have any thing omitted. He is the poet of the body and of the soul, of the passions and the organs, and of all their manifestations, normal and beautiful, or otherwise. Truth, beauty, goodness, heroism, justice - these he recognizes, receives, and takes courage from them; falsehood, uglines [sic], depravity, cowardice and oppression - he sees these, also, with clear vision, but knows that God and Order reign, not Chaos and the Devil,- and therefore receives them, confident that, for a season, they too have their place.

Of the sexes and sexual relation, no previous poet has spoken so freely and so well. This opinion will doubtless astonish many who have read the book. Nor are we surprised that so many find in the "Enfans d'Adam" only the drunken and obscene ravings of a "new astonishing Phallus worship."

All architecture is what you do to it when you look upon it.
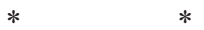

$*$

All music is what awakes from you, when you are reminded by the instruments.

There is such a deep and unmitigated vulgarity and coarseness in the inner life of the people, that no direct allusion can be made to the sexual relations without exciting simpering smiles and blushes, or rude, profane mirth. What of moral elevation, simplicity and genuine purity can there be in a people that persists in speaking of the limbs of a table or chair? We are disgusted with this substitution of seeming for being, and the insufferable cant and hypocrisy to which it gives rise. Thou, friend, who hast hitherto seen nothing but the madness of phallic processions in this poem, go wash thyself, make thyself clean, then return to it and reflect. Think of what precise thing thou hast hitherto made the phallus a symbol, and with what associations-what thou hast done to it when looking upon $i t$ ! And then decide where the obscenity resides.

As for us, we heartily thank Walt Whitman for the clear, distinct, manly and pure voice with which he has spoken of these things, and hail it as the dawn of a wiser and better era, in which men and women will no longer speak of the limbs of tables and chairs. Nor will any pure and ingenuous mind torture this into an endorsement of rude, low and lascivious talk, but will rather receive it as the indication of an intense desire to be at once and forever free from all such.

We have much more to say of Walt — strong, brave lover of man, and uncompromising champion of man's rights, that he is - but must defer it to a more convenient opportunity. In the meantime, we would advise all who have escaped the dominion of the passions and the appetites, and who have any appreciation of the essential dignity of man and the grandeur of his destiny, to buy the book, and read it.

T. V. 


\section{NOTES}

1 Thayer and Eldridge's advertisements appeared in the Liberator on October 26 and November 9, 1860. Thayer and Eldridge went out of business, in December, before they could publish either Jacobs' Incidents in the Life of a Slave Girl or Whitman's Banner at Day-Break.

2 Thayer and Eldridge introduced the work with a public statement: "A large percentage on each copy sold is secured by contract to the family of Captain John Brown, and every purchaser thereby becomes a contributor to a charitable object, which appeals to all freemen with a force that is irresistible."

3 "The Autobiography of William Wilde Thayer"; unpublished manuscript dated November 1, 1892, Manuscript Division, Library of Congress. 